\title{
Optimization of Subcritical Ethanol Extraction for Xanthone from Mangosteen Pericarp
}

\author{
Nuttawan Yoswathana and M. N. Eshtiaghi
}

\begin{abstract}
Mangosteen pericarp has been used for long time as traditional medicine. One of main active ingredient in mangosteen pericarp is xanthone. Xanthone has remarkable effects on cardiovascular, antiviral, and anti-inflammatory. Subcritical ethanol extraction (Sc-ethanol) was employed to extract xanthone from dried mangosteen pericarp and compared with maceration and soxhlet extraction. The Sc-ethanol was applied by various temperature $(80,120$ and $\left.160^{\circ} \mathrm{C}\right)$, ethanol concentration $(50,72.5$ and $95 \%)$ and extraction time (10, 20 and $30 \mathrm{~min}$.) for 1:20 of sample to solvent ratio. The Box-Behnken design was applied to investigate the optimum condition of Sc-ethanol extration. The optimum conditions from Box-Behnken design to obtain the highest xanthone were determined at the optimum conditions as following; temperature $160^{\circ} \mathrm{C}$, extraction time $30 \mathrm{~min}$ in $95 \%$ ethanol. The results presented that for maceration, soxhlet and Sc-ethanol extractions in $0.5 \mathrm{~h}$, the extracted xanthones were 28.31, 31.26 and $57.42 \mathrm{mg} / \mathrm{g}$ of dried mangosteen pericarp respectively.
\end{abstract}

Index Terms-Mangosteen pericarp, maceration, soxhlet, subcritical ethanol extraction, xanthone.

\section{INTRODUCTION}

Mangosteen (Garcinia mangostana Linn.) is in Guttiferae family that is tangerine-size and is deep purple in color on the outside, with a bright white pulp in the inside [1]. It is known as "The Queen of Fruits" because of its excellent flavor. It's grown in Thailand and Southeast Asian countries. The fruit pericarp of this plant has been used for long time as a traditional medicine for treatment of abdominal pain, diarrhea dysentery, infected wound, suppuration, and chronic ulcer [2] Xanthone is the major active ingredient in mangosteen pericarp. The xanthone structure is a very interesting scaffold for different groups in different positions leading to a large variety of pharmacological activities. The xanthone derivative has a remarkable effect on antiulcerogenic [3], antifungal activity [4], antibacterial activity [5], [6], inhibitors of proteinkinase [7], anticancer activity [8], antioxidant [9], [10] and anti-inflammatory [11], [12]. Due to its pharmacological activities, it is popularly applied to herbal cosmetics and pharmaceutical products.

There are mainly two ways to extract mangosteen pericarp. The first way is the tradition extraction techniques such as

Manuscript received May 5, 2014; revised July 7, 2014. This work was supported in part by the Faculty of Engineering, Mahidol University, and The Government Pharmaceutical Organization (GPO), Bangkok, Thailand.

N. Yoswathana and M. N. Eshtiaghi are with the Department of Chemical Engineering, Faculty of Engineering, Mahidol University, Salaya, Phuthamonthol ampur, Nakornprathom Province, Thailand 73170 (corresponding author: N. Yoswathana; e-mail: nuttawan.yos@mahidol.ac.th, mohamman.esh@ mahidol.ac.th). soxhlet extraction and maceration. The second way is novel extraction techniques such as ultrasonic assisted extraction and subcritical ethanol extraction. Soxhlet extraction has been used for a long time. During soxhlet extraction, fresh solvent can repeatedly bring to contact with sample many times and the system remains at a high temperature [13]. Maceration is very simple method that is just soaking material in solvent for long time. It has been developed for many applications such as food preparation, sewage treatment and winemaking process [14]. Subcritical fluid extraction is the method that using fluid under external pressurization above its boiling point such as $100^{\circ} \mathrm{C}$ for water and $78.3^{\circ} \mathrm{C}$ for ethanol. The most studied subcritical fluid extraction was subcritical water extraction (SCWE). Subcritical or superheated water extraction (SCWE) on essential oils is a new technique based on the use of water, at temperatures between $100{ }^{\circ} \mathrm{C}$ and 374 ${ }^{\circ} \mathrm{C}$ and pressure high enough to maintain the liquid state [15]. It is also called pressurized hot water extraction (PHWE) or pressurized low polarity water extraction (PLPWE). Under subcritical state, water is much less polar and organic compounds are much more soluble than at room temperature. The most important advantages of SCWE over traditional extraction techniques are shorter extraction time, higher quality of the extract, lower costs of the extracting agent, and an environmentally compatible technique [16]. The applications of subcritical water for extraction, it can be used to extract antioxidant compounds from rosemary plants [17] as well as to extract whitening agents and azo dyes in paper samples [18], anthocyanins from red grape skin [19].

Box-Behnken designs (BBK) are experimental designs and generally used to find response surface methodology. The BBK designs have advantages that reduce experiments due to it require only three levels and it is efficiency to prepare and explain when compare to the full factorial design and other methods [20]. The extraction methods were used to extract xanthone and alpha mangostin from mangosteen pericarp that were performed with soxhlet extraction, maceration and subcritical ethanol extraction for comparison of extracts from each methods.

\section{MATERIALS AND METHODS}

\section{A. Materials}

Dried mangosteen (Garcinia mangostana Linn.) pericarps were obtained from Government Pharmaceutical Organization (GPO, Thailand). For lab study, the dried mangosteen pericarp was crushed by hammer and grounded with grinder (5657 HAAN, Retsch, GERMANY) to obtain 3 $\mathrm{mm}$ particle size. The dried mangosteen pericarp powder was 
packed in plastic bags and stored in darkness.

\section{B. Chemicals and Reagents}

95\% Ethanol was purchased from Alcoh-A (Thailand). 99.9\% Methanol was purchased from Burdick \& Jackson (Korea). Xanthone standard was purchased from Sigma Chemical Company (St. Louis, MO, USA).

\section{Maceration}

The experiment was performed in a $250 \mathrm{ml}$ beaker filled with $5 \mathrm{~g}$ dried mangosteen powder in $100 \mathrm{ml}$ of $95 \% \mathrm{v} / \mathrm{v}$ ethanol. The extraction was carried out at room temperature for $0.5,1$ and 2 hours without shaking.

\section{Soxhlet}

A classical Soxhlet apparatus was employed in which $5 \mathrm{~g}$ of grounded mangosteen pericarp was placed into cartridge with $250 \mathrm{ml}$ of $95 \% \mathrm{v} / \mathrm{v}$ ethanol in round bottom flask. Extraction was carried out at boiling point $\left(78.1^{\circ} \mathrm{C}\right)$ of ethanol for $0.5,1$ and 2 hours.

\section{E. Subcritical Ethanol Extraction}

The extraction was carried out in a laboratory equipment (volume of vessel, $50 \mathrm{ml}$ ) and pilot scale (volume of vessel, $5 \mathrm{~L}$ ) immersed in oil bath. The extraction was conducted at different ethanol concentration, temperature, extraction time and sample: solvent relation. The Box-Behnken design was applied to determine the response pattern of percentage of ethanol $\left(X_{1}\right)$, temperature $\left(X_{2}\right)$ and extraction time $\left(X_{3}\right)$, respectively at the constant of sample to solvent ration as 1:20 $(w / v)$, with three levels for each variable. While the dependent variable was the xanthone extracts. The symbols and levels are shown in Table I. The whole design consisted of 15 experimental points, which were carried out in a randomized order, to maximize the effect of unexplained variability in the observed response due to extraneous factors.

TABLE I: BOX-BEHNKEN DESIGNA FOR SUBCRITICAL ETHANOL EXTRACTION

\begin{tabular}{|c|c|c|c|}
\hline \multirow[b]{3}{*}{$\begin{array}{c}\text { experi } \\
\text { ment }\end{array}$} & \multicolumn{3}{|c|}{ Coded Level } \\
\hline & $X_{1}$ & $X_{2}$ & $X_{3}$ \\
\hline & $\begin{array}{c}\text { Ethanol } \\
\text { concentration } \\
(\%)\end{array}$ & $\begin{array}{c}\text { temperature } \\
\left({ }^{\circ} \mathrm{C}\right)\end{array}$ & $\begin{array}{l}\text { time } \\
(\mathrm{min} .)\end{array}$ \\
\hline 1 & $0(72.5)$ & $-1(80)$ & $-1(10)$ \\
\hline 2 & $0(72.5)$ & $-1(80)$ & $1(30)$ \\
\hline 3 & $0(72.5)$ & $1(160)$ & $-1(10)$ \\
\hline 4 & $0(72.5)$ & $1(160)$ & $1(30)$ \\
\hline 5 & $-1(50)$ & $0(120)$ & $-1(10)$ \\
\hline 6 & $-1(50)$ & $0(120)$ & $1(30)$ \\
\hline 7 & $1(95)$ & $0(120)$ & $-1(10)$ \\
\hline 8 & $1(95)$ & $0(120)$ & $1(30)$ \\
\hline 9 & $-1(50)$ & $-1(80)$ & $0(20)$ \\
\hline 10 & $-1(50)$ & $1(160)$ & $0(20)$ \\
\hline 11 & $1(95)$ & $-1(80)$ & $0(20)$ \\
\hline 12 & $1(95)$ & $1(160)$ & $0(20)$ \\
\hline 13 & $0(72.5)$ & $0(120)$ & $0(20)$ \\
\hline 14 & $0(72.5)$ & $-1(80)$ & $-1(10)$ \\
\hline 15 & $0(72.5)$ & $-1(80)$ & $1(30)$ \\
\hline
\end{tabular}

${ }^{\mathrm{a}}$ The values in parentheses mean practical levels.

The extracts of soxhlet, maceration and subcritical ethanol extraction was filtrated through filter paper no. 1 and removed solvent by using rotary evaporator (R-215, BUCHI Rotavapor, Switzerland) at $60^{\circ} \mathrm{C}$ under vacuum. $99 \%$ v/v methanol was added for adjust volume to $25 \mathrm{ml}$. After that, the extract was subjected to analysis of xanthone concentration.

\section{F. Analytical Method for Xanthone}

The concentration of xanthones was determined by High-Performance Liquid Chromatographic system (UV 1000/P2000, Thermo Separation Products, California, USA), equipped with an UV-detector was set at $319 \mathrm{~nm}$ (was applied). The chromatographic separation was performed at room temperature on an Alltima ${ }^{\circledR} \mathrm{C}-18$ analytical column (250 $\mathrm{mm} \times 4.6 \mathrm{~mm}$, i.d., Ilinoid, USA) by injection volume was $20 \mu \mathrm{l}$ at flow rate $1.5 \mathrm{ml} / \mathrm{min}$.

\section{G. Statistical Analysis}

All of the experiments were carried out in triplicate, and the average of xanthone was taken as a responsive value. Analyses of the variance were used to determine the significant difference between results.

\section{RESULTS AND DISCUSSIONS}

\section{A. Maceration}

In general was the xanthone yield during maceration lower than soxhlet extraction. Increasing the maceration time has slight effect on xanthone recovery. The amount of extracted xanthone during 0.5 to $2 \mathrm{~h}$ maceration was between 28.13 to $31.55 \mathrm{mg} / \mathrm{g}$ dried sample as seen in Fig. 1. According to the soaking or maceration in solvent at room temperature is a very slow diffusion process with small mass transfer during soaking.

\section{B. Soxhlet}

In Fig. 1, it was the effect of extraction time on xanthone yield demonstrated. With increasing the extraction time increased the yield. Soxhlet extraction after 0.5 to $2 \mathrm{~h}$ resulted the xanthone recovery up to $41.41 \mathrm{mg} / \mathrm{g}$ dried sample. Due to the high temperature extraction improved the efficiency of extraction since heat renders the cell walls permeable, increased solubility and diffusion coefficient.

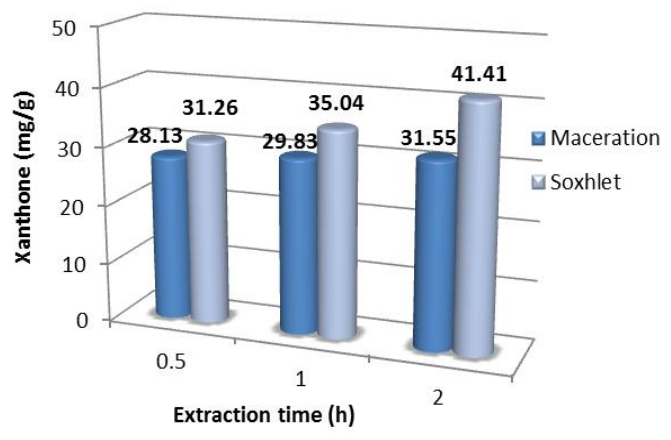

Fig. 1. Effect of extraction time on maceration and soxhlet.

\section{Subcritical Ethanol Extraction}

\section{1) Effect of sample to solvent ratios}

In general, the sample to solvent ratio significantly affected to extraction yield. For the experiment, subcritical ethanol was applied to investigate this effect as shown in Fig. 2. The extraction was carried out in the laboratory equipment immersed in oil bath. The extraction constant conditions were at extraction time $30 \mathrm{~min}$ and temperature $160^{\circ} \mathrm{C}$ in $95 \%$ 
ethanol.

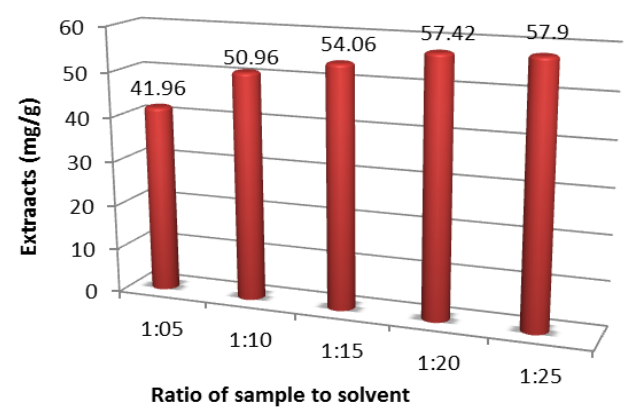

Fig. 2. Effect of the sample to solvent ratio.

The yield of xanthone was 41.96, 50.69, 54.06, 57.42 and $57.90 \mathrm{mg} / \mathrm{g}$ dried sample, after extraction in solvent ratio 1:5, $1: 10,1: 15,1: 20$ and $1: 25(\mathrm{mg} / \mathrm{ml})$ in $95 \%(\mathrm{v} / \mathrm{v})$ ethanol, respectively as shown in Fig. 2. Xanthone was increased with the increasing of solvent ratio. It increased because of at high solvent ratio the substances could easier dissolved than at low solvent ratio due to the increasing of contact surface.

\section{2) Effect of extraction times}

The effect of different extraction time $(0.5,1$ and 2$)$ on xanthone yield was investigated at 1:20 (mg/ml) solvent ratio and temperature $160^{\circ} \mathrm{C}$ in $95 \%$ (v/v) ethanol as viewed in Fig. 3 .

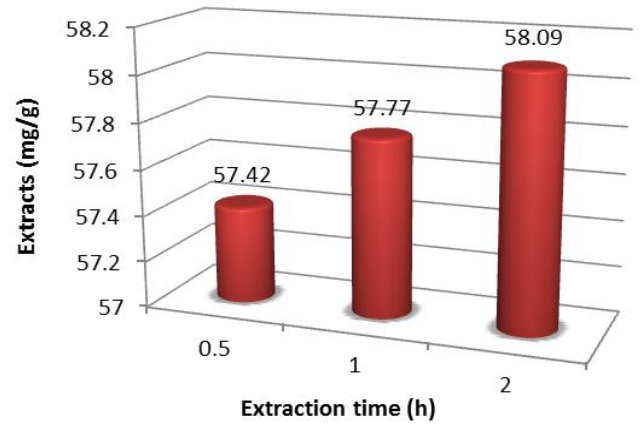

Fig. 3. Effect of extraction time on subcritical ethanol extraction.

The yield of xanthone was $57.42,57.77$ and $58.09 \mathrm{mg} / \mathrm{g}$ dried sample at $0.5,1$ and $2 \mathrm{~h}$ respectively as shown in Fig. 3 . This result indicated that the maximum extraction yield was obtained at 2 hours extraction time. Nearly no increasing of xanthone extracts within 0.5 to $2 \mathrm{~h}$ could be detected with increasing of extraction time. Xanthone was increased with increasing of extraction time that means 30 min extraction time was long enough to extract xanthone at applied technique conditions.

\section{3) Optimization of xanthone from mangosteen pericarp using subcritical ethanol extraction}

The values of response (xanthone extracts) at different experimental combinations are given in Table I, which showed that there was a considerable variation in xanthone within the range of the subcritical ethanol extraction conditions. The statistical model, representing xanthone as a function of the independent variables under investigation, can be expressed by the following quadratic equation (1):

$$
\begin{gathered}
Y=14.4544-0.1296 X_{1}+0.0661 X_{2}-0.1214 X_{3}+ \\
1.66 \times 10^{-3} X_{1} X_{3}
\end{gathered}
$$

where $Y$ is xanthone extraction ( $\mathrm{mg} / \mathrm{g}$ dried sample), $X_{1}, X_{2}$ and $X_{3}$ are the coded variables for percent ethanol, extraction time and temperature, respectively. Effects of percent ethanol, extraction time and temperature on xanthone recovery as shown in Fig. 4 to Fig. 6.

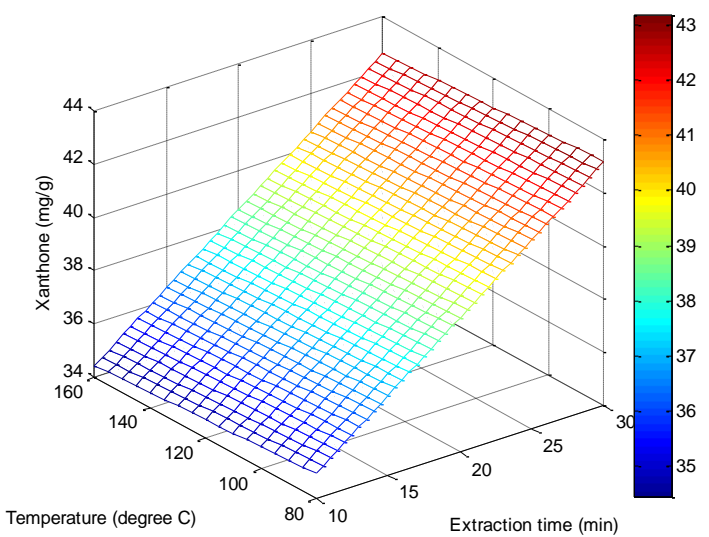

Fig. 4. Response surface plot showing the effect of temperature and extraction time on xanthone recovery, percent ethanol was constant at $72.5 \%$ $(\mathrm{v} / \mathrm{v})$ ethanol.

From Fig. 4, xanthone increased with increasing of temperature and percent ethanol by the temperature had low effect when compared with extraction time.

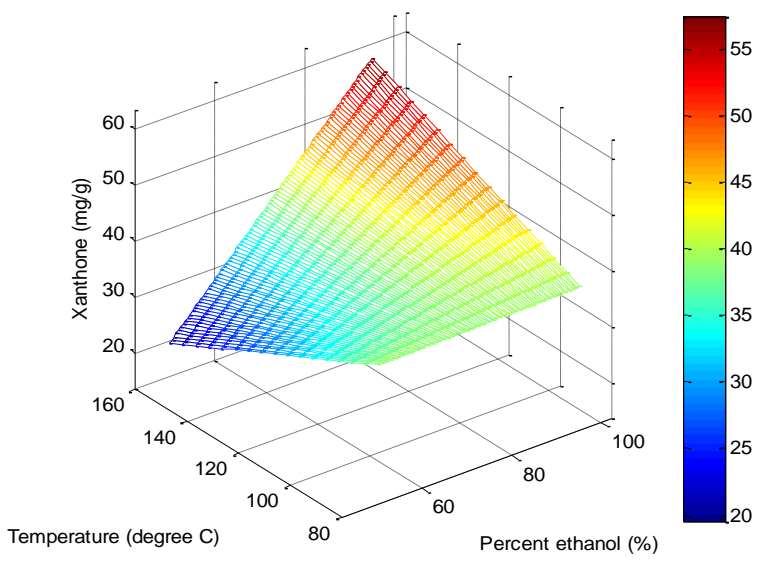

Fig. 5. Response surface plot showing the effect of temperature and percent ethanol on xanthone, the extraction time was constant at 20 minute.

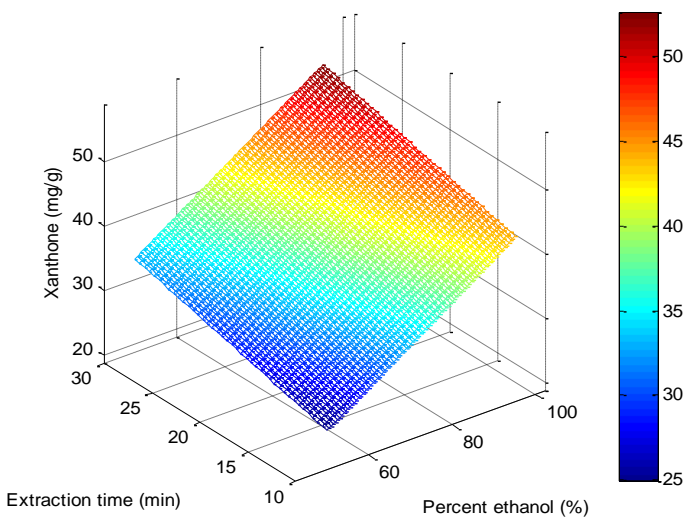

Fig. 6. Response surface plot showing the effect of extraction time and percent ethanol on xanthone recovery, temperature was constant at $120^{\circ} \mathrm{C}$.

The xanthone increased with increasing of temperature at high percent ethanol but the effect reversed at low percent ethanol in Fig. 5. Because of low percent ethanol, extraction 
solvent had more water content, water in subcritical state could be oxidizing agent that damaged xanthone. Increasing of temperature increased oxidizing agent (water) and decreased xanthone. The oxidation in water at a condition above the critical point was known as supercritical water oxidation (SCWO) [21], while the oxidation using water at a condition below the critical point was referred to as subcritical wet oxidation (WO) [22].

In Fig. 6, xanthone extraction was increased with increasing of percent ethanol and extraction time. The increasing of percent ethanol, extraction time and temperature increased solubility of xanthone in solvent.

In this research, the fit model gave the value of $R^{2}(0.9148)$ that it indicated a good agreement between the experimental and predicted values of xanthone. The value of adjusted $R^{2}$ $(0.8676)$ suggests that the total variation of $87 \%$ for xanthone was attributed to the independent variables, and about $13 \%$ of the total variation could not be explained by the model. The $P$-value of the model was significant $(P<0.05)$ that indicated the model exhibited a good fitness to the true behavior.

\section{4) Validation of the model}

In order to validate the accuracy of the model equation (eq. 1), a verification experiment was carried out under the optimum condition ( $95 \%$ ethanol, extraction time $30 \mathrm{~min}$ and temperature $160^{\circ} \mathrm{C}$ ) within the experimental range. Under the optimum condition, the model predicted a maximum response of $57.90 \mathrm{mg} / \mathrm{g}$ dried sample. The experimental result showed xanthone extraction of $57.42 \mathrm{mg} / \mathrm{g}$ dried sample. It has acceptable value from the predicted value within the $95 \%$ confidence interval.

\section{Comparison between Extractability of Xanthone and Alpha Mangostin Using Novel Technique (Sc-ethanol) and Conventional Metho}

For this experiment, all of extraction methods extracted with 1: 20 of sample to solvent ratio and $0.5 \mathrm{~h}$ extraction time. Subcritical ethanol extraction (Sc-ethanol) was applied at temperature $160^{\circ} \mathrm{C}$ in $95 \%$ ethanol.

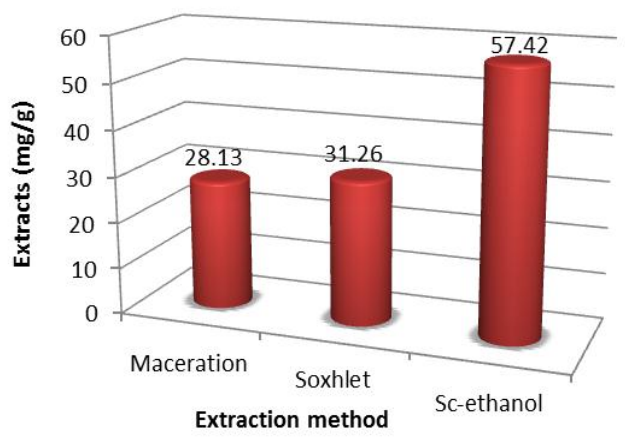

Fig. 7. Comparison between extractability of xanthone and alpha mangostin using Sc-ethanol) and conventional method at extraction time $0.5 \mathrm{~h}$.

The yields of xanthone were 28.13, 31.26 and $57.42 \mathrm{mg} / \mathrm{g}$ dried sample, after extraction using maceration, soxhlet and Sc-ethanol in $95 \%$ (v/v) ethanol extraction, respectivelyin Fig. 7. Therefore, the novel technique as subcritical ethanol extraction showed much higher xanthone than conventional techniques as maceration and soxhlet extraction.

\section{CONCLUSIONS}

The xanthone extracts from mangosteen pericarp by using subcritical ethanol extraction was compared to maceration and soxhlet extraction by applied constant extraction time and sample to solvent ratio. The subcritical ethanol extraction applied with Box-Behnken design showed the highest xanthone recovery and higher than up to 2 times. The response surface methodology was proved to be useful for investigated the optimum conditions of xanthone extraction. The statistical analysis showed that the optimum conditions for this technique were temperature $160^{\circ} \mathrm{C}, 95 \%$ ethanol as solvent and shorter extraction time within $30 \mathrm{~min}$ for mangosteen pericarp. Therefore, the subcritical ethanol extraction is an alternatively efficient technique for bioactive substances from herb or plants extraction.

\section{ACKNOWLEDGMENT}

The authors thank Faculty of Engineering, Mahidol University for financial support of this conference and The Government Pharmaceutical Organization (GPO) for materials and analytical equipment. We also thank to Department of Chemical Engineering, Mahidol University for supported equipment and work place.

\section{REFERENCES}

[1] J. F. Morton, Fruits of from Warm Climates, New York, USA: Creative Resource Systems Inc, 1978, pp.1439-1445.

[2] W. Mahabusarkam, P. Wiriyachtra, and W. Taylor, "Chemical constituents of Garcinia managostana," J. Nat. Prod., vol. 50, pp. 474-478, 1987.

[3] D. Shankaranarayarn, G. gopolakrishnan, and L. Kameswaran, "Pharmacological profile of mangostin and its derivatives," Arch. Int. Pharmacodyn., vol. 239, pp. 257-269, 1979.

[4] G. gopolakrishnan, B. Banumathi, and G. Suresh, "Evaluation of the antifungal activity of natural xanthones from Garcinia mangostana and their synthetic derivatives, J. Nat. Prod., vol. 60, pp. 519-524, 1977.

[5] M. Iinuma, H. Tosa, T. Tanake, F. Asai, and K. Miyauchi, "Antibacterial activity of xanthones from guitferaeus plants methicillin-resistant Staphylococcus aureus," J. Pharm. Pharmacol, vol. 48, pp. 861-865, 1996.

[6] T. M. Chomnawang, S. V. Surassmo, and W. Gritsanapan, "Antimicrobial effects of Thai medical plants against acne-inducing bacteria," J. Ethnopharmacol, vol.101, pp. 330-333, 2005.

[7] W. Jinsart, B. Ternai, D. Buddhasukh, and G. M. Polya, "Inhibition of wheat embryo calcium dependent protein kinase and other kinase by mangostin and gamma-mangostin," Phyto-chemistry, vol. 31, pp. 3711-3713, 1992.

[8] S. Tewtrakul, C. Wattanapiromsakul, and W. Mahabusarakam, "Effects of compounds from Garcinia mangostana on inflammatory mediators in RAW264.7 macrophage cells," J. Ethopharmacol., vol. 121, pp. 379-382, 2009.

[9] L. J. Harrison, "Xanthones from the heartwood of Garcinia mangostana," Phytochemistry, vol. 60, pp. 541-548, 2002.

[10] H. A. Jung, B. N. Su, W. J. Keller, and A. D. Konghorn, "Antioxidant xanthones from pericarp of Garcinia mangostana (mangosteen)," $J$. Agri. Food. Chem., vol. 54, pp. 247-254, 1971.

[11] L. G. chen, L. L. Yang, and C. C. Wang, "Antiinflammatory activity of alpha mangostins from Garcinia mangostana," Food Chem. Toxicol., vol. 48, pp. 861-865, 2008.

[12] S. Suksamrarn, O. Komutiban, P. Ratananukul, N. Chimonoi, N. Lartpornmatulee, and A. Suksamrarn, "Cytotoxic prenylated xanthones from the young fruit of Garcinia mangostana," Chem. Pharm. Bull., vol.54, pp. 301-305, 2006.

[13] L. E. Garcia and M. D. Luque, "Focused microwave assistance as a solver of conventional Soxhlet extraction drawbacks," Trends in Analytical Chemistry, vol. 20, pp. 28-33, 2001. 
[14] J. L. Cutillas, "Phenolic comounds and color stability of red wines: Effect of skin maceration time," American Journal of Enology and Viticulture, vol. 52, pp. 266-270, 2001.

[15] P. Rungsriwong, N Rangkadilok, J. Satayavivad, M. Goto, and A. Shotipruk, "Subcritical waterextraction of polyphenolic compounds from Terminaliachebula Retz. fruits," Separation and Purification Technology, vol. 66, pp. 51-56, 2009.

[16] M. Herrero, A. Cifuentes, and E. Ibanez, "Sub- and supercritical fluid extraction of functional ingredients from different natural sources: Plants, food-by-products, algae and microalgae: A review," Food Chemistry, vol. 98, pp. 136-148, 2006.

[17] E. Ibanez, A. Kubatova, F. J. Senorans, S. Cavero, G. Reglero, and S. B. Hawthorne, "Subcritical water extraction of antioxidant compounds from rosemary plants," J. Agri. Food. Chem, vol. 51, pp. 375-382, 2003.

[18] M. Santos, R. Batlle, J. Salafranca, and C. Nerin, "Subcritical water and dynamic sonication-assisted solvent extraction of fluorescent whitening agents and azo dyes in paper samples," J. Chromatogr., vol. 1064, no. 2, pp.135-41, February 2005.

[19] Z. Y. Yu and L. R. Howard, "Subcritical water and sulfured water extraction of anthocyanins and other phenolics from dried red grape skin," Journal of Food Science, vol. 70, pp. 270-276, 2005.

[20] S. L. Ferreira, R. E. Bruns, H. S. Fereira, G. D. Mators, J. M. David, and G. C. Brandao, "Box-Behnken design: An alternative for the optimization of analytical methods," Anal. Chim. Acta, vol. 597, pp. 179-186, 2007.
[21] E. F. Gloyna and L. Li, "Supercritical water oxidation research and development update, Environmental Progress, vol. 143, pp. 182-192, 1995.

[22] V. S. Mishra, V. Mahajani, and J. Joshi, "Wet air oxidation," Industrial and Engineering Research, vol. 34, pp. 2-48, 1995.

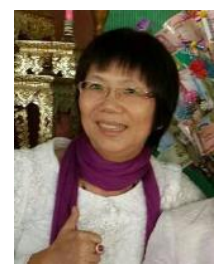

Nuttawan Yoswathana works at the Department of Chemical Engineering, Faculty of Engineering, Mahidol University, Salaya, Phuthamonthol Ampur, Nakornprathom Province, Thailand, 73170. Her research fields are bioactive substances and oil extraction from agricultural wastes from industry and Thai herbal using novel extraction techniques such as Supercritical carbon dioxide $\left(\mathrm{ScCO}_{2}\right)$, subcritical water extraction (SCW), high hydrostatic pressure (HHP), high electric field pulse (HELP) and ultrasonic, including encapsulation of plant extracts are in micron powders and nano-materials. For environmental management, the research fields are advanced oxidation process such as Fenton/ UV-Fenton, air pollution control via absorption, cyclone, solid waste management in community, including safety in chemical operations. 